\title{
熱容量の異なる木質壁体の熱的特性に基づく 住宅の省エネルギー効果*1
}

\author{
山崎真理子*2, 平野佳祐*3, 佐々木康寿*4, 水谷章夫*5, \\ 崔哲*5, 榊原勝已*6

\section{Influence of Wall Composition on Thermo-Physical Properties and Energy-Saving in Wooden Houses*1}

\author{
Mariko YAMASAKI*2, Yoshihiro HIRANO*3, Yasutoshi SASAKI*4, \\ Akio MizuTANI ${ }^{* 5}$, Zhe CuI ${ }^{* 5}$ and Katsumi SAKAKIBARA *6
}

\begin{abstract}
As one of the countermeasures against global warming, it is effective to make use of wood resources that serve as carbon storage and improve energy-saving efficiency of buildings. In this study, it is examined how the wall composition of a wooden house affects indoor thermal environments and its energy-saving effects. Three types of wooden wall panels with different compositions are used to examine each type's thermo-physical properties by JIScompliant tests as well as large-scale tests with experimental buildings. Moreover, power consumption of a heated building was also measured in order to make clear the effect of the wall composition of a wooden house on energysaving. The obtained results are as follows : 1 . Coefficients of overall heat transmission were qualitatively larger in the following order : general mud wall $>$ wall composed of wood and mud > wall primarily composed of heat insulating material. 2. The air-conditioner's power consumption was larger in the following order : house with mud walls $>$ house with walls composed of wood and mud $>$ insulation-type house. As the temperature difference between indoors and outdoors increased, this tendency became more notable. 3. In the cases of insulation-type houses, the ratio of electric power consumption for heating to temperature difference between indoors and outdoors was generally constant, while in the case of a house with walls composed of wood and mud or with mud walls, the ratio was not constant, denoting the effect of heat capacity. 4. The compound wall of Japanese cedar and mud showed a better heat insulation property than the mud wall, and its energy-saving effect was improved.
\end{abstract}

Keywords : $\quad$ wooden house, wall composition, thermo-physical properties, insulation efficiency, energy-saving.

地球温暖化対策の一つとして，炭素貯蔵機能を有する木材の利用と建物の省エネルギー性の向 上は有効な手段である。本研究では，木造住宅の壁体構成が室内熱環境に及ぼす影響を調べ，省 エネルギー効果を検証した。具体的には，構成が異なる 3 種類の木質壁体を対象に，それぞれの 熱物性を JIS 準拠試験と実験建物を用いた大型試験により調べた。さらに，建物の暖房時の消費 電力を測定し，壁体構成が省エネルギー効果に及ぼす影響を検証した。得られた知見は次の通り である。1．熱貫流率は，一般的な土壁>木材と土壁を複合させた壁体>断熱材を主とする壁体 の順に大きい。2．エアコンの消費電力は，土壁住宅 $>$ 木材・土複合壁体の住宅 $>$ 断熱型住宅の 順に大きく，この傾向は室内外温度差が大きくなるほど顕著に現れた。3．断熱型住宅の場合に は暖房消費電力／室内外温度差の比が概ね一定となった。一方，木材・土複合壁体の住宅および 土壁住宅ではこの比が一定とならず，熱容量の影響が見受けられた。4.木材・土壁複合壁体は 土壁と比べて断熱性能が改善されており，これに伴い省エネルギー効果が認められた。

\footnotetext{
${ }^{* 1}$ Received May 30, 2008 ; accepted July 23, 2008. 本研究の一部は，第58回日本木材学会大会（2008年 3 月，つくば）に おいて発表した。 *2 岐阜工業高等専門学校 Gifu National College of Technology, Motosu 501-0495, Japan *3 名古屋大学農 学部 Faculty of Agriculture, Nagoya University, Nagoya 464-8601, Japan *4 名古屋大学大学院生命農学研究科 Graduate School of Bioagricultural sciences, Nagoya University, Nagoya 464-8601, Japan *5 名古屋工業大学大学院工学研究科 Graduate School of Technology, Nagoya Institute of Technology, Nagoya 466-8555, Japan *6 株式会社明城 Meijyo Co. Ltd., Anjo 444-1202, Japan
} 


\section{1. 緒言}

一般に，木材・木質材料・木造建物は優れた断熱 性や吸放湿性を有すると考元られており，これに関 して既に多くの研究がなされている何えば1-12)。特に， 住宅の壁体を対象とした研究では，麓らが枠組壁工 法の壁体寸法に近い各種の木質試験壁体を対象とし て，保護熱箱方式の実験によりその熱物性を明らか にしている4)。また，信田らは木質パネル工法にお ける壁内温度分布および壁体の熱物性を現場測定に より明らかとした6,7)。ただし，住宅内の居住温熱 環境は建物仕様・室容積・気密性・断熱性などの内 的要因と, 気候・方角・周辺環境などの外的要因が 複雑に絡み合って形成されるために, 例えば壁体単 体の特性や一壁体の住宅モデルなど個々の特性を単 に追求するだけでは，木質住宅の温熱環境に対して 総合的な評価を与えることは難しい。

近年, 地球規模で問題となっている温暖化への対 策として, 省エネルギー性能の向上や, 炭素固定・ 炭素貯蔵機能を有する木材の利用は有効であり, こ の観点から，木造住宅の断熱性能や冷暖房負荷に対 する性能を改めて評価することが重要である。木造 工法の中には，主に土壁や板壁を用いた伝統工法住 宅がある一方で，近年多く建設されている高気密・ 高断熱型住宅があり，両者の特徴には様々な違いが ある。環境負荷の観点で見れば，断熱性能に優れた 現代型住宅の方が高い省エネルギー効果を示すと考 えられるが，伝統工法住宅は天然素材を利用してい る点で建材自体の低環境負荷性に優れている。今後 の木造住宅のあり方を考えると，伝統工法住宅と現 代型住宅それぞれの長所を融合させていくことが重 要であり，そのためにも両者の性能を同一実験で比 較, 検討し, その差異を明確にすることは意義があ る。

そこで，本研究では，同一の室容積・外的条件下 の木造実大実験建物 3 棟（伝統的な土壁建物, 現代 的な断熱型建物, 木材と土壁を併用した天然素材仕
様の建物）を建築し，建材や仕様が居住環境，特に 温湿度環境に及ぼす影響を検討している ${ }^{13-16)}$ 。

本報では，特に壁体構成に焦点を絞り，壁体の熱 的特性を基に暖房時の消費電力量を検証し，木造住 宅の壁体構成と省エネルギー効果との関係を調べる ことを目的とした。すなわち，まず，小試験体を対 象とした熱伝導率測定試験（JIS A 1412-2-1999 準 拠)，および実験建物を対象とした大型熱伝導率測 定試験を行い, 各壁体の熱物性を測定した。さらに, 実験建物の暖房時の温度変動と消費電力量を調べ た。

\section{2. 試験方法}

\section{1 壁体構成}

本実験で用いた壁体は，板壁と土壁を複合させた 壁体（以後，Type 1 とする)，一般的な土壁（同 Type 2), 現在広く普及している一般的な断熱型住 宅仕様の壁体（同 Type 3）の 3 種類である。各壁体 の構成を Table 1 に, 壁体のサンプル断面写真を Fig. 1 に示す。 3 種類の壁体は特に内部構成が大き く異なっており, Type 1 は $40 \mathrm{~mm}$ 厚スギ (Cryptmeria japonica）板 $+40 \mathrm{~mm}$ 厚土壁から, Type 2 は70 mm 厚 の土壁から成り，また Type 3 は内部に $100 \mathrm{~mm}$ 厚グ ラスウール断熱材（密度 $16 \mathrm{~kg} / \mathrm{m}^{3}$ ) を配した断熱性 能の高い壁体構成となっている。

\section{2 熱物性の測定}

\subsubsection{JIS 準拠試験}

各壁体の熱物性を調べるために，「JIS A 1412-21999 熱絶縁材の熱抵抗及び熱伝導率の測定方法 第 2 部：熱流計法 (HFM 法)」に準拠して小試験体 を対象とした測定を行った。小試験体の寸法は，外 寸 $360 \times 360 \mathrm{~mm}^{2}$, 壁体部 $300 \times 300 \mathrm{~mm}^{2}$ であり, 厚 さは80 mm（Type 2 のスギ下見板が無い場合） 125 $\mathrm{mm}$ （Type 3）である。試験体は作成後 3 ケ月以上 恒温恒湿の実験室内で養生した。壁体の外周 4 面は $30 \mathrm{~mm}$ 厚のヒノキ材枠で囲った。実験では, Fig. 2

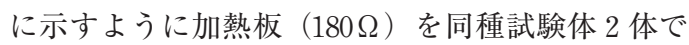

Table 1. Wall structure of JIS-specimens and experimental wooden houses.

\begin{tabular}{|c|c|c|c|c|c|c|}
\hline & \multicolumn{2}{|c|}{ Type 1} & \multicolumn{2}{|c|}{ Type 2} & \multicolumn{2}{|c|}{ Type 3} \\
\hline & Material & $\begin{array}{c}\text { Thickness } \\
(\mathrm{mm})\end{array}$ & Material & $\begin{array}{c}\text { Thickness } \\
(\mathrm{mm})\end{array}$ & Material & $\begin{array}{c}\text { Thickness } \\
(\mathrm{mm})\end{array}$ \\
\hline \multirow[t]{4}{*}{ Inner side } & $\mathrm{Mud}^{\mathrm{a})}$ & 10 & Mud $^{\text {a) }}$ & 10 & Plaster board & 12 \\
\hline & Lumber & 40 & Mud $^{\mathrm{b})}$ & 70 & Glass wool & 100 \\
\hline & Mud $^{\text {b) }}$ & 40 & Lumber $^{c}$ & $(8-9)$ & & \\
\hline & Waterproof sheet & 1 & Waterproof sheet & 1 & Waterproof sheet & 1 \\
\hline Outer side & Lumber & 5-15 & Lumber $^{\mathrm{d})}$ & 5-15 & Siding board & 12 \\
\hline
\end{tabular}

Note: ${ }^{\text {a) }}$ Intermediate coat. ${ }^{\text {b) }}$ Scratch coat. ${ }^{\text {c) }}$ Lath wood. ${ }^{\text {d) }}$ Clapboard. 


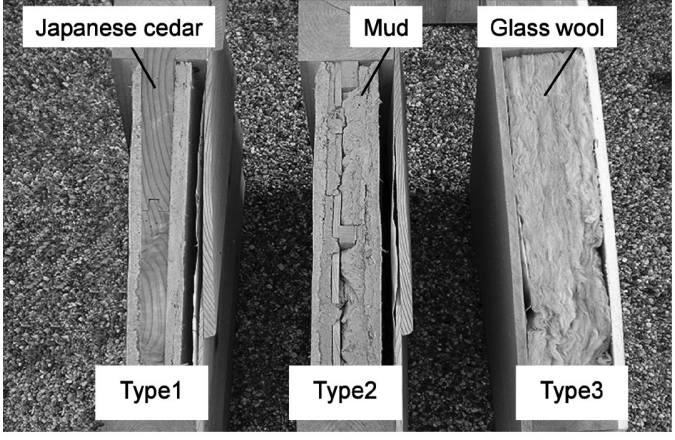

Fig. 1. Cross sectional view of wall samples.

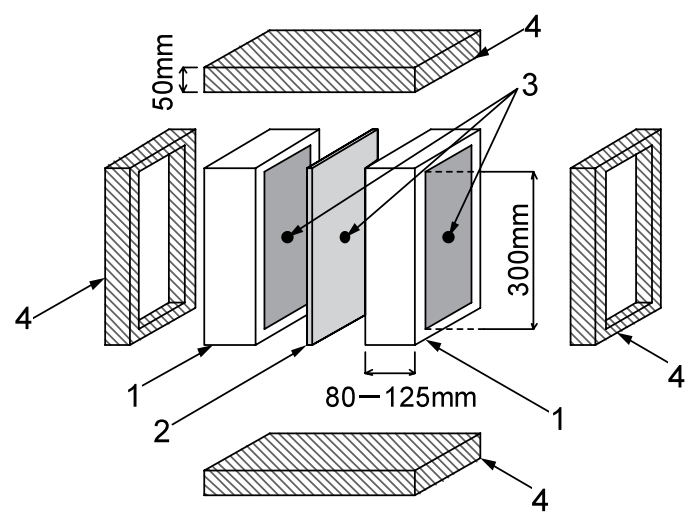

Fig. 2. Specimen set-up of the JIS-compliant test.

Legend: 1: Wall specimen with wood frame, 2 : Heater, 3 : Thermocouple (T-type), 4 : Heat insulator.

Note: Temperature of both surfaces of each wall specimen and heater was measured.

挟み，試験体外側表面を除く外周 4 面（ヒノキ材枠 面）を押出発砲ポリスチレンフォーム断熱材（厚さ $50 \mathrm{~mm}$ ) で断熱した。実験装置の写真を Fig. 3 に示す。 加熱は電圧制御とし, 加熱板の表面温度が $70^{\circ} \mathrm{C}$ を超 えないように設定した。測定項目は加熱板の消費電 力, 加熱板中央の表面温度, 試験体 2 体それぞれの 内側（加熱板側）および外側（室内側）中央の表面 温度，および実験室内の温度であり，測定間隔は実 験開始後しばらくは10分，温度上昇が緩やかになっ た後は30分とした。消費電力は電力計（HIOKI 製デ ジタルパワーハイテスタ3181-02）を用いて，また 温度はJIST型熱電対と温度データロガー (ADVANTEST 製マルチチャンネルデジタルレコー ダーTR2724）を用いて測定した。実験は恒温実験 室内（平均室温 $22.2^{\circ} \mathrm{C}$ ) で行った。

\subsection{2 大型試験}

実大木質壁体を対象とした熱物性試験として，麓

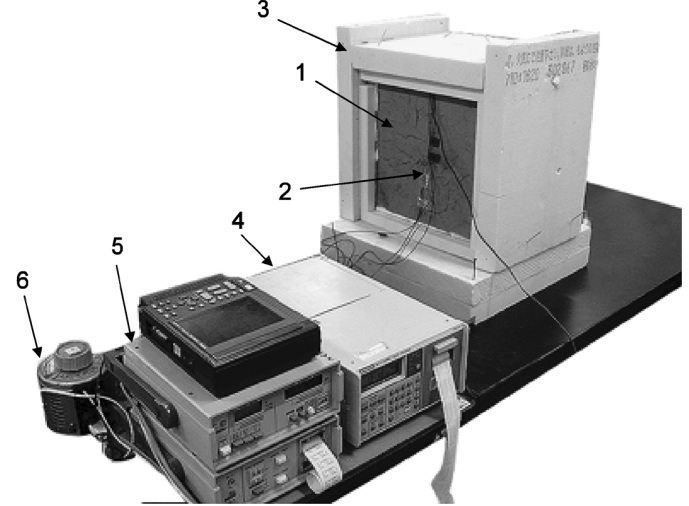

Fig. 3. Measuring device of the JIS-compliant test.

Legend: 1: Specimen, 2: Thermocouple (T-type), 3 : Heat insulator, 4 : Data logger for temperature, 5 : Data logger for electric power, 6 : Transformer.

らが実験室内で行った保護熱箱法による測定 ${ }^{4)}$ や信 田が行った現場測定 ${ }^{7)}$ がある。本研究で実施した試 験法は現場測定であるが，信田が室内外の温度差を 強制的に設け，その際の壁体通過熱量を熱流素子に より測定したのと異なり，平板加熱法による大型熱 伝導率測定試験を準拠した。

具体的には，JIS 準拠試験で用いた壁体構成と同 一の壁体構成（詳細は Table 1 に示すとおり）を有 する木造実験建物 3 棟（Fig. 4）を対象として，実 大壁体の熱貫流率を測定した。実験建物は愛知県安 城市の同一敷地内に立地し，身区体構造および室容積 （床面積 $4 \times 4 \mathrm{~m}^{2}$ ，天井高 $2.8 \mathrm{~m}$ ）は同一である。屋 根は Type 1 および Type 2 では日本瓦＋土莫き（70 mm 厚), Type 3 では洋瓦莫きである。加熱板には 一般家庭用のホットカーペットを用い，各建物の東 面内壁の 1 畳分を直接加熱した。Fig. 5 にカーペッ

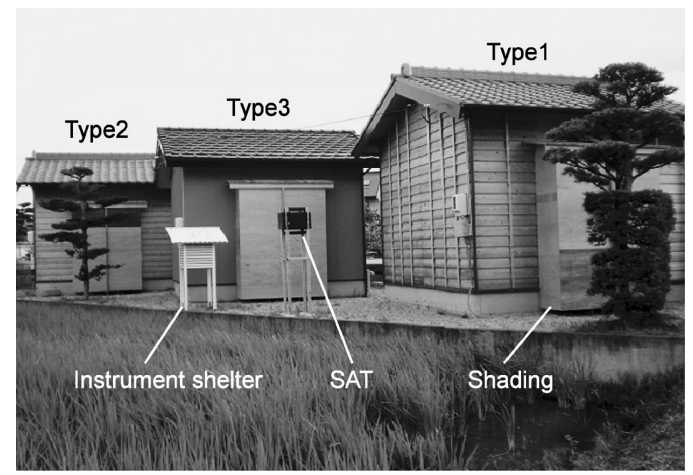

Fig. 4. Experimental houses.

Legend: SAT : Measurement of sol-air temperature. 


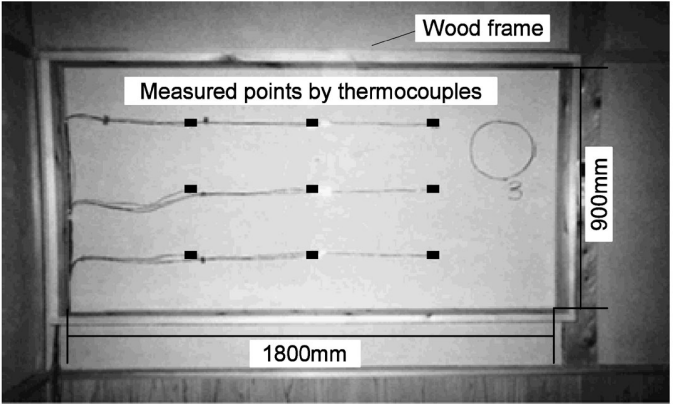

Fig. 5. Arrangement of inner wall for the large-scale test with an experimental building, showing the measuring positions for temperature.

卜設置前の東面内壁の写真を示す。カーペットを写 真中の木枠の中に嵌め込み，カーペットと木枠間の 僅かな隙間を脱脂綿により充填した。Fig. 6 には大 型実験の断面模式図を示す。室内側への熱流を遮断 するためにカーペットの室内側に硬質ウレタンフォ 一ム断熱材（厚さ100 mm）を配した。加熱は電圧 制御とし，加熱板の表面温度が $70^{\circ} \mathrm{C}$ を超えないよう

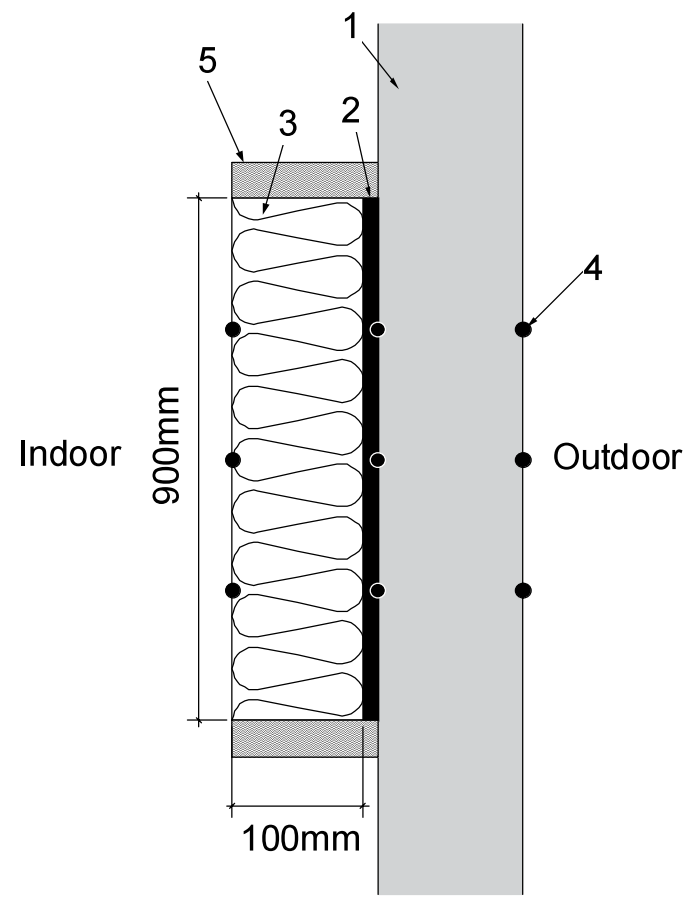

Fig. 6. Vertical section of wall at the large-scale test, showing the measuring positions for temperature.

Legend: 1: Wall, 2: Heater of hot carpet rag, 3 : Heat insulator, 4 : Thermocouple (T-type), 5 : Wood frame.
に設定した。測定項目はカーペットの消費電力，断 熱材室内側表面温度（3 箇所），カーペット表面温 度 ( 9 箇所), 内壁表面温度 ( 9 箇所), 外壁表面温 度 ( 3 箇所), および室内温度, 外気温（百葉箱内 温度）であり，測定間隔は10分とした。消費電力は クランプ電力計 (HIOKI 製クランプオンパワーハイ テスタ 3169）を用いて，また温度はJIS T 型熱電対 と温度データロガー（江藤電気製フラッシュデータ ロガー・サーモダック F）を用いて測定した。大型 試験の測定期間は，2007年12月21日から2008年 1 月 9 日とした。

なお，本試験では加熱面積が大きく，加熱面内に 温度分布が生じると考えられることから，加熱時の 内壁温度分布を赤外線サーモグラフィ (NEC 三栄 製サーモトレーサ TH-9100）を用いて測定した。

\section{3 暖房負荷試験}

前節の大型試験を行った実験建物を対象として, 建物の壁体構成が暖房負荷に及ぼす影響を検討する ために, 暖房時の建物内の温度変動と消費電力量を 調べた。本実験では，全ての棟において，天井㧍よ び床を断熱仕様とし，小屋裏換気口を塞ぎ，空を遮 光した。設置したエアコンはダイキン製ルームエア コン S28GTSS-W（エネルギー消費効率：冷房時 5.77，暖房時6.27）である。

暖房の設定温度は $20,24,28^{\circ} \mathrm{C}$ の 3 条件とし，そ れぞれ $3 \sim 5$ 日間継続して暖房した。測定項目はエ アコンの 1 時間毎の消費電力量，および10分毎の室 内温度と外気温（百葉箱内温度）である。消費電力 は電力計 (埼広エンジニヤリング株式会社製省エネ ナビ P303型）を用いて，また温度は大型試験の場 合と同様に測定した。試験期間は2008年 2 月23日か ら同年 3 月 7 日とした。

\section{3. 結果と考察}

\section{1 壁体の温度変化および加熱面の温度分布}

Fig. 7 および Fig. 8 に, JIS 準拠試験, 大型試験そ れぞれに打ける温度変動の一例を示す。なお， Fig. 8 では, 各測定面の温度を面内の測定点 3 点ないし 9 点の平均值とした。

Fig. 7 より, Type 1 と Type 2 のそれぞれに熱量 10 $\mathrm{W}$ を与えた場合, Type 1 では加熱板表面温度が 60 ${ }^{\circ} \mathrm{C}$ 以上に，また試験体の内側表面温度は約 $45^{\circ} \mathrm{C}$ まで 上昇したが, 試験体の外側表面は室温とほぼ同じ温 度で推移した。これに対して, Type 2 では加熱板 表面温度が約 $45^{\circ} \mathrm{C}$ までしか上昇せず, 試験体の内側

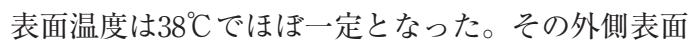
温度は室温と比べて約 $5 \sim 8{ }^{\circ} \mathrm{C}$ 高くなった。一方, 

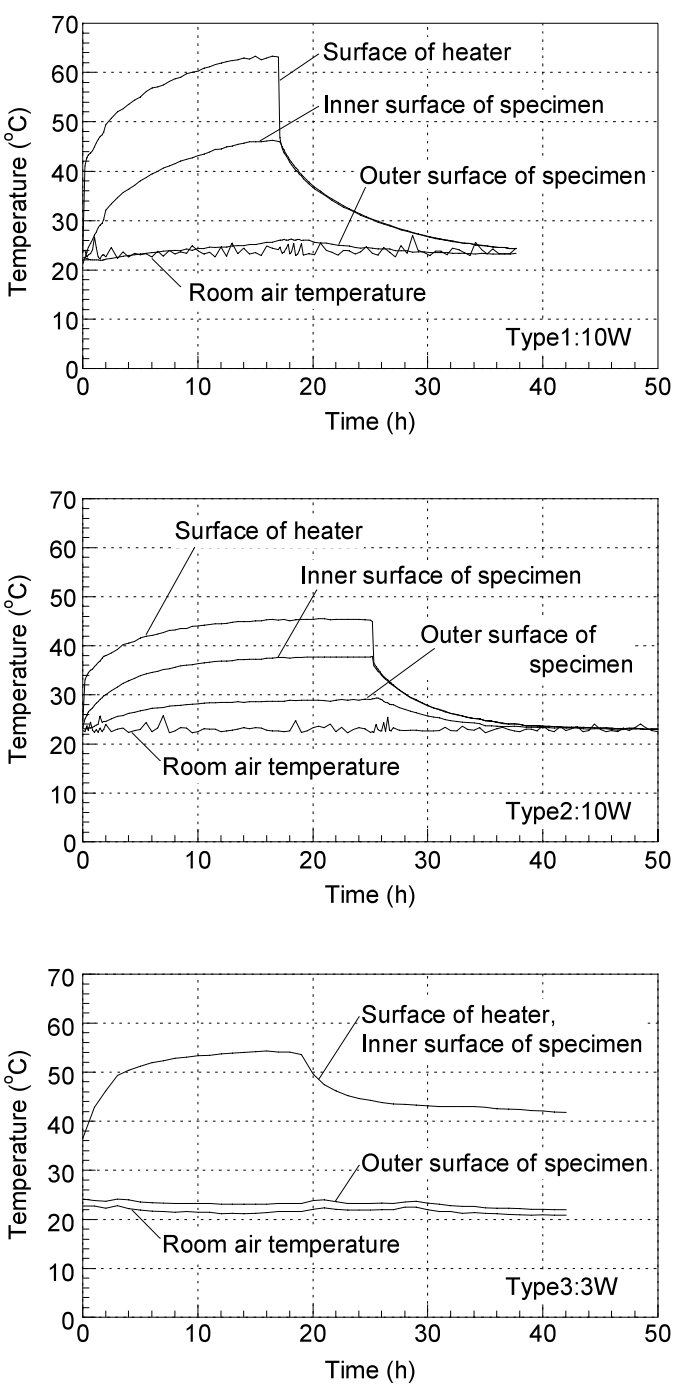

Fig. 7. Examples of temperature changes obtained by the JIS-compliant test.

Type 3 については，わずか $3 \mathrm{~W}$ の熱量を与えただ けで加熱板表面および試験体の内側表面温度が $55^{\circ} \mathrm{C}$ 付近まで上昇したが, 試験体の外側表面温度は全く 変化しなかった。以上のことから，まず，Type 3 では試験体両表面の温度差が大きく，すなわち壁体 の断熱性が非常に大きいことが確かめられた。これ に対して, Type 2 は両表面の温度差が小さいことか ら，壁体の断熱性は小さいことがわかる。Type 1 では, Type 2 と比べて両表面の温度差が大きいこと から，断熱性は向上したと考えられる。一方，Type 3 と比べると, 同じ実験経過時間であっても温度一 定となっておらず，蓄熱の影響がかなり見受けられ
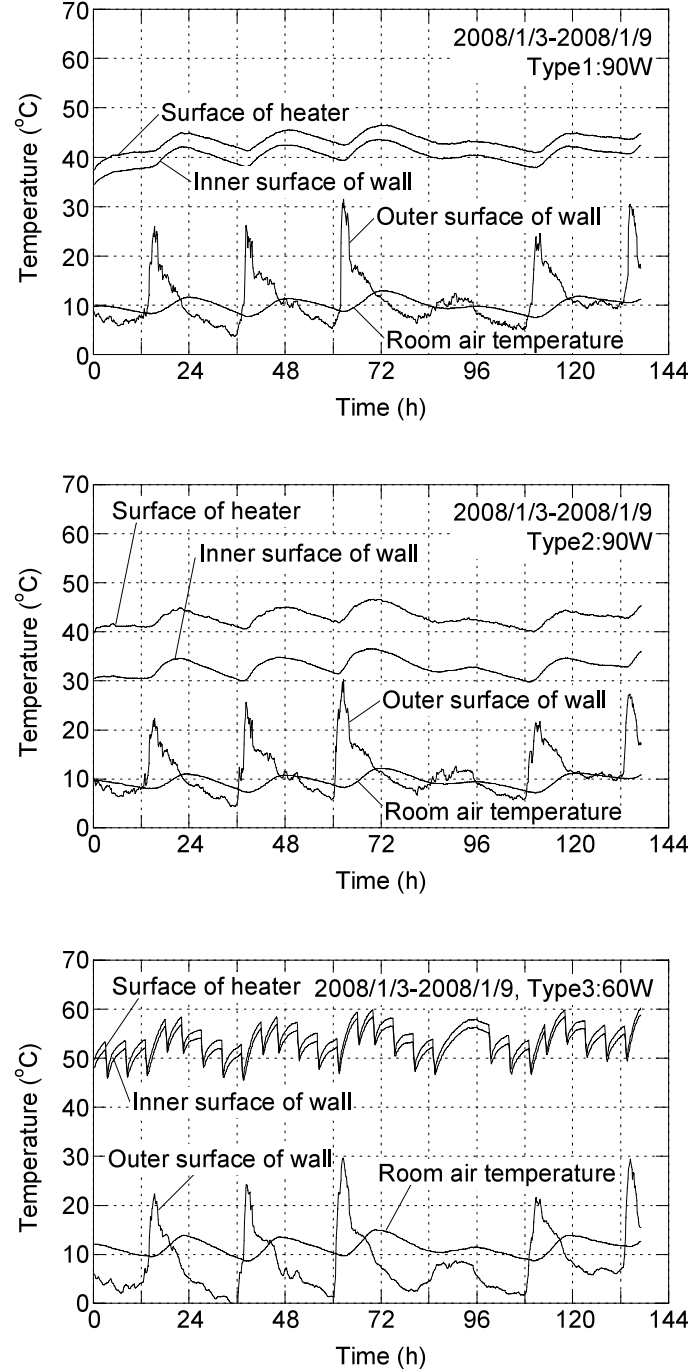

Fig. 8. Examples of temperature changes obtained by the large-scale test.

た。

Fig. 8 より大型試験の結果を見ると, Type 3 は Type 1 およびType 2 より少ない熱量でカーペット 表面温度掞よび内壁表面温度の上昇が著しく, 両者 の温度差が小さい。また, Type 1 と Type 2 を比較 すると，同じ熱量を与えた場合に内壁表面の温度上 昇はType 1 の方が大きい。これらの傾向は，JIS 準 拠試験の傾向と同様である。

Fig. 9 には，大型試験における内壁の加熱面内温 度分布を熱画像により示す。上述のように，内壁温 度は壁体により大きく異なる。ここでは各壁体の温 度分布を明確にするために, 壁体毎に温度表示の範 

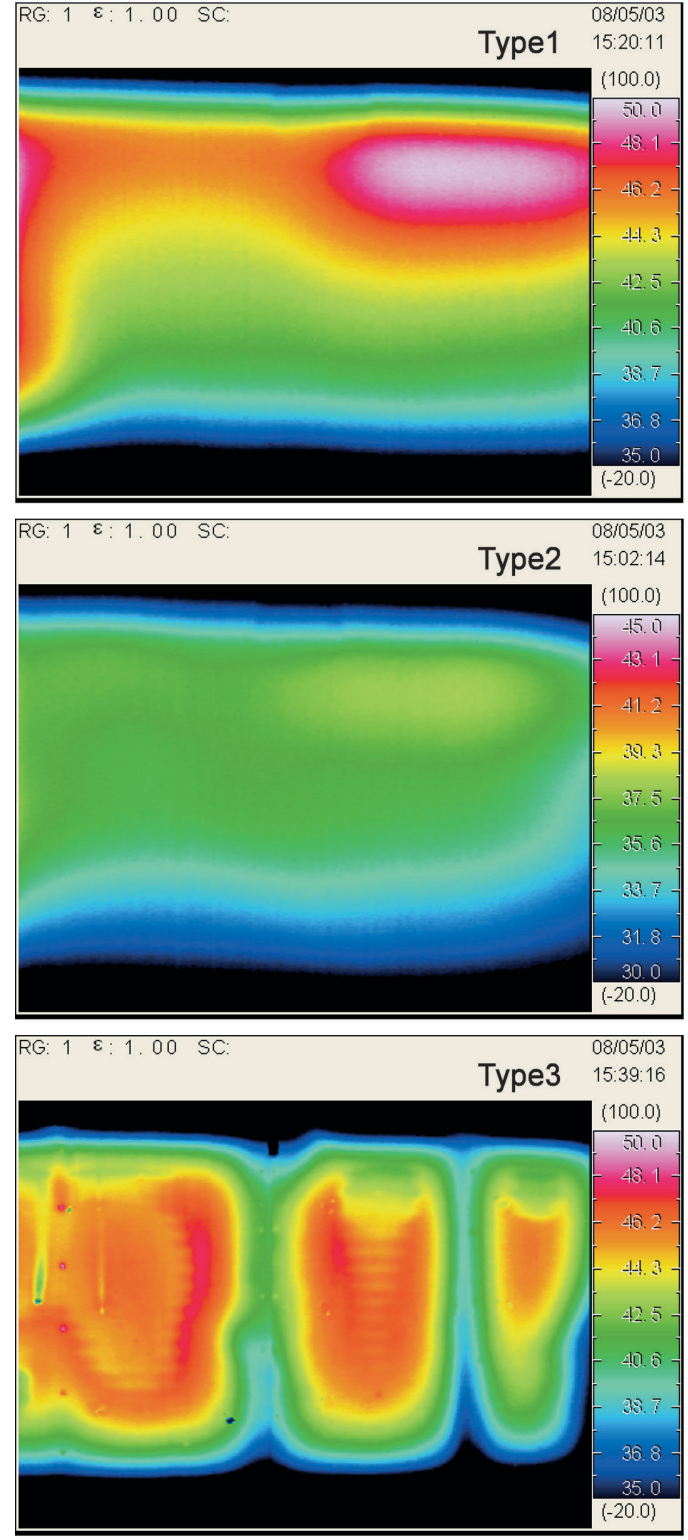

Fig. 9. Examples of temperature distribution of heated walls by the large-scale test.

囲を定めた。ただし，温度幅は $15^{\circ} \mathrm{C} に$ 統一した。 Fig. 9 に示すように, Type 3 では明確な温度分布が 認められた。これについて, Type 3 の低温度部分は 壁体内部に $50 \mathrm{~cm}$ 間隔で配されている間柱位置と概 ね一致している。これにより断熱材と木材の熱伝導 率の違いから，すなわち木材が熱橋となって温度分 布が生じたものと考えられる。これに対して, Type 2 は加熱面内全体の温度分布が概ね均一である。ま た, Type 1 は Type 2 に比べると加熱面内上部の温
度が高温になっている。この理由として加熱面内の 空気層の対流による影響などが考えられ，さらに， Type 2 と比べて Type 1 は壁体の断熱性が大きいた めに，加熱面内により明確な温度分布が生じたもの と考えられる。

\section{2 熱貫流率}

JIS 準拠試験および大型試験の結果，得られた各 壁体の熱物性值を Table 2 および Table 3 に示す。壁 体表面の温度変動より定常状態と考えられる部分に ついて, 実験で測定した加熱板の発熱量 $Q$ と壁体(試 験体）の内 - 外表面温度差 $\Delta \theta$ から熱コンダクタン ス $C$ を求めた。算出式は, JIS 準拠試験, 大型試験 のそれぞれについて次式(1)，(2)で示される。式中, $A$ は加熱板の表面積 (JIS 準拠試験 $A_{\mathrm{J}}=0.09 \mathrm{~m}^{2}$, 大 型試験 $\left.A_{\mathrm{h}}=1.57 \mathrm{~m}^{2}\right)$ である。

$$
\begin{aligned}
C & =\frac{Q}{\left(\Delta \theta \cdot 2 \cdot A_{\mathrm{J}}\right)}\left(\frac{\mathrm{W}}{\mathrm{m}^{2} \cdot \mathrm{K}}\right) \\
C & =\frac{\left(Q-Q_{i}\right)}{\left(\Delta \theta \cdot A_{\mathrm{h}}\right)}\left(\frac{\mathrm{W}}{\mathrm{m}^{2} \cdot \mathrm{K}}\right) \\
Q_{i} & =\frac{\Delta \theta_{i} \cdot A_{\mathrm{h}}}{2.5}(\mathrm{~W})
\end{aligned}
$$

大型試験については，式(2)に示すように室内側に 配した断熱材から室内への流出熱量 $Q_{i}$ を考慮した。 ここで， $Q_{i}$ は断熱材の熱抵抗を 2.5 , 加熱板の表面 温度と断熱材の室内側表面温度との差を $\Delta \theta_{i}$ とし て，上式(3)により求めた。また，Fig. 9 に示したよ うに特に Type 3 では温度分布が見られるが，ここ では各測定面内の平均值を用いて算出した。大型試 験では，日射などの外的環境により特に外壁表面温 度が日内変動するので，定常に近い状態とみなすこ とができる夜間あるいは雨天・曇天時に㧍ける測定 值を用いて熱コンダクタンス $C$ を求めた。

算出した熱コンダクタンス $C$ より見かけの熱伝 導率 $\lambda$ を式(4)により，また熱貫流抵抗 $R$ および熱 貫流率 $K$ を式(5)により求めた。式中， $d$ は壁体厚 さである。また， $\alpha_{\mathrm{i}}$ は室内側熱伝達率 $\left(9 \mathrm{~W} / \mathrm{m}^{2} \cdot \mathrm{K}\right)$, $\alpha_{0}$ は外気側熱伝達率 $\left(23 \mathrm{~W} / \mathrm{m}^{2} \cdot \mathrm{K}\right)$ として計算した。

$$
\begin{aligned}
\lambda & =d \cdot C\left(\frac{\mathrm{W}}{\mathrm{m} \cdot \mathrm{K}}\right) \\
R & =\frac{1}{K}=\frac{1}{\alpha_{\mathrm{i}}}+\frac{1}{\sum_{j} \frac{d_{j}}{\lambda_{j}}}+\frac{1}{\alpha_{0}} \\
& =\frac{1}{\frac{1}{\alpha_{\mathrm{i}}}+\frac{1}{C}+\frac{1}{\alpha_{0}}}\left(\frac{\mathrm{m}^{2} \cdot \mathrm{K}}{\mathrm{W}}\right)
\end{aligned}
$$

さらに，式(5)に示す熱貫流抵抗の定義から熱貫流 率の計算值（設計值）を算出し，これを Table 2 お 
Table 2. Coefficients of overall heat transmission of small specimen by the JIS A 1412-2-compliant test.

\begin{tabular}{|c|c|c|c|c|c|c|c|c|c|c|c|}
\hline \multirow{2}{*}{$\begin{array}{l}\text { Specimen } \\
\text { No. }\end{array}$} & \multicolumn{2}{|c|}{ Condition } & \multirow{2}{*}{$\begin{array}{c}\text { Thickness } \\
d \\
(\mathrm{~m})\end{array}$} & \multirow{2}{*}{$\begin{array}{c}\text { Heat value } \\
Q \\
(\mathrm{~W}) \\
\end{array}$} & \multirow{2}{*}{$\begin{array}{l}\Delta \theta^{\mathrm{a})} \\
\left({ }^{\circ} \mathrm{C}\right)\end{array}$} & \multirow{2}{*}{$\begin{array}{c}C^{\mathrm{b})} \\
\left(\mathrm{W} / \mathrm{m}^{2} \cdot \mathrm{K}\right)\end{array}$} & \multirow{2}{*}{$\begin{array}{c}\lambda^{\mathrm{c})} \\
(\mathrm{W} / \mathrm{m} \cdot \mathrm{K})\end{array}$} & \multicolumn{2}{|c|}{$K\left(\mathrm{~W} / \mathrm{m}^{2} \cdot \mathrm{K}\right)^{\mathrm{d})}$} & \multirow{2}{*}{$\begin{array}{c}R^{\mathrm{e})} \\
\left(\mathrm{m}^{2} \cdot \mathrm{K} / \mathrm{W}\right)\end{array}$} & \multirow{2}{*}{$\left(\begin{array}{c}\left.a^{\mathrm{f}}\right) \\
\left(\mathrm{m}^{2} / \mathrm{h}\right)\end{array}\right.$} \\
\hline & Clapboard & Airspace & & & & & & $\begin{array}{c}\text { Experimental } \\
K_{\mathrm{e}}\end{array}$ & $\begin{array}{c}\text { Calculated } \\
K_{\mathrm{c}}\end{array}$ & & \\
\hline \multirow{4}{*}{ Type 1} & \multirow{2}{*}{$\bigcirc$} & & 0.107 & 10 & 24.4 & 2.28 & 0.24 & 1.69 & 1.34 & 0.59 & - \\
\hline & & & 0.107 & 15 & 34.8 & 2.40 & 0.26 & 1.75 & 1.34 & 0.57 & - \\
\hline & & \multirow{2}{*}{-} & 0.092 & 10 & 21.9 & 2.54 & 0.23 & 1.83 & 1.63 & 0.55 & 0.0015 \\
\hline & & & 0.092 & 15 & 35.2 & 2.37 & 0.22 & 1.73 & 1.63 & 0.58 & 0.0015 \\
\hline \multirow{5}{*}{ Type 2} & \multirow{2}{*}{ O } & \multirow{2}{*}{$\bigcirc$} & 0.112 & 10 & 15.5 & 3.58 & 0.40 & 2.31 & 2.26 & 0.43 & - \\
\hline & & & 0.112 & 15 & 25.5 & 3.27 & 0.37 & 2.17 & 2.26 & 0.46 & - \\
\hline & \multirow{3}{*}{ 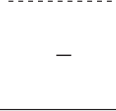 } & \multirow{3}{*}{-} & 0.080 & 10 & 7.0 & 6.00 & 0.48 & 3.11 & 3.27 & 0.32 & 0.0029 \\
\hline & & & 0.080 & 15 & 10.2 & 8.17 & 0.65 & 3.61 & 3.27 & 0.28 & 0.0029 \\
\hline & & & 0.080 & 20 & 11.4 & 9.79 & 0.78 & 3.90 & 3.27 & 0.26 & 0.0029 \\
\hline Type 3 & - & - & 0.125 & 3 & 30.9 & 0.54 & 0.07 & 0.50 & 0.38 & 2.01 & - \\
\hline
\end{tabular}

Note : ${ }^{\text {a) }}$ Temperature difference on both surfaces of wall specimen. ${ }^{\text {b) }}$ Thermal conductance. ${ }^{c}$ Thermal conductivity.

d) Coefficients of overall heat transmission. ${ }^{\text {e) }}$ Thermal resistance. ${ }^{\text {f) }}$ Thermal diffusivity.

Table 3. Coefficients of overall heat transmission of walls by large-scale tests with experimental buildings.

\begin{tabular}{|c|c|c|c|c|c|c|c|c|}
\hline \multirow[b]{2}{*}{ Wall No. } & \multirow{2}{*}{$\begin{array}{c}\text { Thickness } \\
d \\
(\mathrm{~m})\end{array}$} & \multirow{2}{*}{$\begin{array}{c}\text { Heat value } \\
Q \\
(\mathrm{~W})\end{array}$} & \multirow{2}{*}{$\begin{array}{c}Q-Q_{i}{ }^{\mathrm{a})} \\
(\mathrm{W})\end{array}$} & \multirow{2}{*}{$\begin{array}{l}\Delta \theta^{\mathrm{b})} \\
\left({ }^{\circ} \mathrm{C}\right)\end{array}$} & \multirow{2}{*}{$\begin{array}{c}C^{\mathrm{c})} \\
\left(\mathrm{W} / \mathrm{m}^{2} \cdot \mathrm{K}\right)\end{array}$} & \multirow{2}{*}{$\begin{array}{c}\lambda^{\mathrm{d})} \\
(\mathrm{W} / \mathrm{m} \cdot \mathrm{K})\end{array}$} & \multicolumn{2}{|c|}{$K\left(\mathrm{~W} / \mathrm{m}^{2} \cdot \mathrm{K}\right)^{\mathrm{e}}$} \\
\hline & & & & & & & $\underset{K_{\mathrm{e}}}{\text { Experimental }}$ & $\begin{array}{c}\text { Calculated } \\
K_{\mathrm{c}}\end{array}$ \\
\hline \multirow{3}{*}{ Type 1} & 0.105 & 71.8 & 54.9 & 26.0 & 1.34 & 0.14 & 1.11 & 1.19 \\
\hline & 0.105 & 83.2 & 63.9 & 27.6 & 1.47 & 0.15 & 1.20 & 1.19 \\
\hline & 0.105 & 90.1 & 69.2 & 29.0 & 1.52 & 0.16 & 1.23 & 1.19 \\
\hline \multirow{3}{*}{ Type 2} & 0.095 & 68.7 & 53.1 & 19.9 & 1.70 & 0.16 & 1.35 & 1.63 \\
\hline & 0.095 & 82.8 & 63.7 & 20.3 & 2.00 & 0.19 & 1.53 & 1.63 \\
\hline & 0.095 & 89.8 & 69.0 & 21.0 & 2.10 & 0.20 & 1.58 & 1.63 \\
\hline \multirow{3}{*}{ Type 3} & 0.125 & 51.1 & 27.9 & 39.7 & 0.45 & 0.06 & 0.42 & 0.38 \\
\hline & 0.125 & 52.4 & 28.8 & 44.6 & 0.41 & 0.05 & 0.39 & 0.38 \\
\hline & 0.125 & 59.3 & 31.2 & 46.0 & 0.43 & 0.05 & 0.40 & 0.38 \\
\hline
\end{tabular}

Note: ${ }^{a)}$ Quantity of heat passing though the wall. ${ }^{\text {b) }}$ Temperature difference on both surfaces of wall. ${ }^{c}$ Thermal conductance.

d) Thermal conductivity. ${ }^{\text {e }}$ Coefficients of overall heat transmission.

よび Table 3 に併記した。この算出に際して各材料

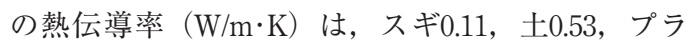
スターボード 0.24 , グラスウール 0.043 , サイディン グ 0.15 とし, 空気層の等価熱伝導抵抗は $0.09 \mathrm{~m}^{2} \cdot \mathrm{K} / \mathrm{W}$ とした ${ }^{17)}$ 。

Table 2 より，JIS 準拠試験による熱貫流率の実験 值 $K_{\mathrm{e}}$ は計算值 $K_{\mathrm{c}}$ と近い值を示した。また, Type 2 について，土壁のみ（スギ下見板なし）の場合の見 かけの熱伝導率 $\lambda$ は $0.48 \sim 0.78 \mathrm{~W} / \mathrm{m} \cdot \mathrm{K}$ であり，この 值は既往の報告 ${ }^{18)}$ と類似していることから，概ね 妥当な実験值と考えている。しかし，熱貫流率が小 さい Type 1 や Type 3 の場合には, 実験值と計算值 の差異がやや大きく, 試験体の厚さ方向以外への損 失熱量が影響したものと推察される。Table 2 に示 すように, 熱貫流率の大きさは Type 2>Type 1> Type 3 であった。すなわち, 壁体の断熱性は Type 3, Type 1, Type 2 の順に優れている。Type 1 は Type 2 における土壁の一部(30 mm 厚)をスギ板 (40 mm 厚)
に代えた壁体であるため，これにより熱伝導率が小 さくなり, 断熱性の改善につながったと考えられる。

Table 3 より, 大型試験による熱貫流率の実験值 $K_{\mathrm{e}}$ と計算值 $K_{\mathrm{c}}$ (大型試験の Type 1, Type 2 につい ては壁内部の空気層を考慮した）の間には，Table 2 の JIS 準拠試験の場合よりさらに良好な一致が認め られた。JIS 準拠試験では加熱面積が壁体厚さの割 に小さいために，わずかな測定值の変動が熱コンダ クタンスの值に影響するが，その点で大型試験では 加熱面積が大きいためにこの影響が小さくなり，結 果的に良好な測定結果が得られたと考えられる。し たがって, 建物の壁体に対して有効な測定法と思わ れる。定性的には, JIS 準拠試験の傾向と同じであり, 壁体内部にスギ板を配したType 1 は土壁のみの Type 2 より高い断熱性能を示した。

\section{3 熱拡散係数}

JIS 準拠試験結果に対して 1 次元非定常伝熱数值 計算を行い，熱拡散係数 $a$ の推定を試みた。壁厚方 
向 1 次元の場合に熱伝導方程式は次式(6)で表され る。

$$
\frac{\partial \theta}{\partial t}=a \cdot \frac{\partial^{2} \theta}{\partial x^{2}}
$$

式中, $t$ は時間（解析では $\partial t=1 \mathrm{~min}$.とした）, $\theta$ は 温度, $x$ は壁厚方向（同 $\partial x=1 \mathrm{~cm}$ ) を示す。数值解 析では Fig. 10に示すように，実測した温度変動（一 例が Fig. 7）を基にして，熱伝導率 $\lambda$ に Table 2 の見 かけの熱伝導率 $\lambda$ を用い，熱拡散係数 $a$ をパラメー 夕とした。Table 2 に解析した熱拡散係数 $a$ を併記 した。見かけの熱伝導率 $\lambda$ を熱拡散係数 $a$ で除して 容積比熱を計算したところ, Type 2（平均793.13 $\mathrm{kJ} / \mathrm{m}^{3} \cdot \mathrm{K}$ ）の方が Type 1 (平均 $542.43 \mathrm{~kJ} / \mathrm{m}^{3} \cdot \mathrm{K}$ ）より 容積比熱が大きく，土とスギの容積比熱の大小関係 と一致した。

\section{4 暖房負荷に及ぼす壁体構成の影響}

各実験建物について室内温度と外気温との差（以 後, 室内外温度差とする) を求め, その 1 時間平均 と同時間帯の消費電力量との関係を調べた。Fig. 11 に結果を示す。ここでは，日射の影響を排除するた めに夜間 (18時から翌 6 時まで)のデー夕を示した。

Fig. 11より, 同一室内外温度差時での消費電力量は Type $2>$ Type $1>$ Type 3 の順に大きい。これは前述 した熱貫流率の大小関係と一致しており，壁体の断 熱性能が高いほど省エネルギー効果を期待できるこ とが確かめられた。また, Fig. 11では室内外温度差 が大きくなるほど壁体間の差異が顕著に現れた。

Fig. 11には，各建物に対して原点を通る回帰直線 を求め，これを併記した。Fig. 11によれば，Type 3 では実験值と回帰直線が概ね一致するが, Type 1 と Type 2 では実験值と回帰直線が一致していない。す なわち, 熱容量が大きい壁体では消費電力と室内外 温度差の間に直線関係が得られず，その原因として 土, 木材による蓄熱の影響が推察される。これより,

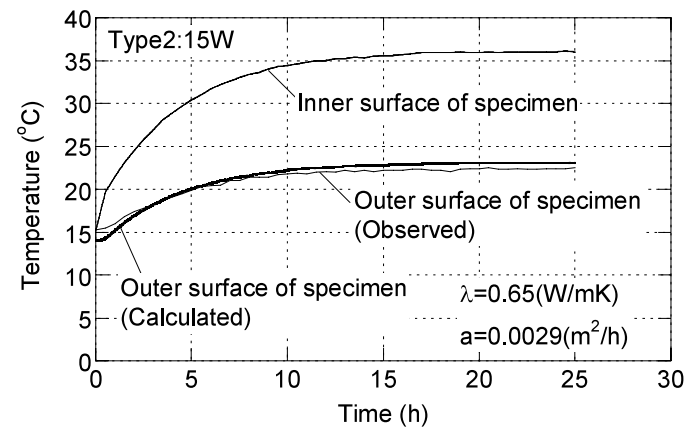

Fig. 10. Numerical analysis of heat transfer of the wall specimen.

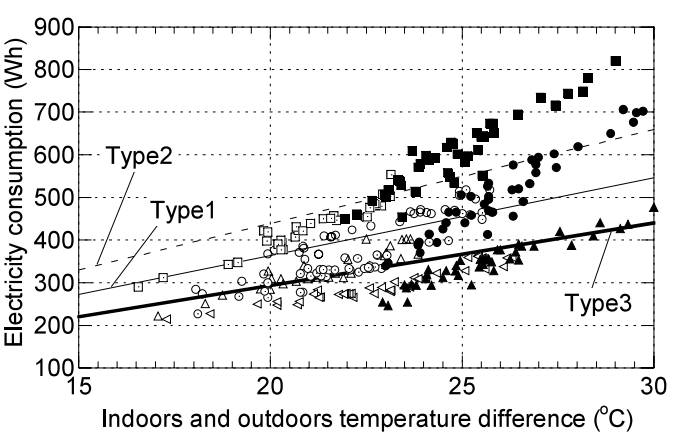

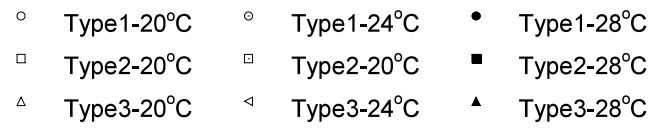

Fig. 11. Relationships between electricity consumption and temperature differences between indoors and outdoors.

本試験のような非定常状態における暖房負荷試験か ら建物の熱損失係数を得ることは, 特に熱容量が大 きい壁体に対しては難しいことがわかった。

\section{4. 結 論}

本研究では, 木造住宅の壁体構成が室内熱環境に 及ぼす影響を明らかにするため, 構成が異なる 3 種 類の壁体についてそれぞれの熱物性を JIS 準拠試験 および実験建物を用いた大型試験により調べた。さ らに, 建物の暖房使用時の消費電力を測定し, 壁体 構成が省エネルギー効果に及ぼす影響を検証した。 得られた知見は次の通りである。

1. 熱貫流率は, 一般的な土壁>木材と土壁を複合 させた壁体＞断熱材を主とする壁体の順に大き い。

2. エアコンの消費電力は，土壁住宅>木材・土複 合壁体の住宅>断熱型住宅の順に大きく，この 傾向は室内外温度差が大きくなるほど顕著に現 れた。

3. 断熱型住宅の場合には暖房消費電力 / 室内外温 度差の比が概ね一定となった。一方，木材・土 複合壁体の住宅および土壁住宅ではこの比が一 定とならず，熱容量の影響が見受けられた。

4. 木材・土壁複合壁体は土壁と比べて断熱性能が 改善されており,これに伴い省エネルギー効果 が認められた。

\section{謝辞}

本研究はトステム建材産業振興財団の研究助成を 受けた。記して謝意を表す。 


\section{文献}

1）“木質環境の科学”, 山田 正編, 海青社, 大津, 1987, pp. 255-351.

2) 信田 聡, 大熊幹章：木材学会誌 26(2), 112117 (1980).

3）平井信之, 斉藤藤一, 牧野哲嗣, 山崎晃嗣：木材 学会誌 26(7), 439-442（1980）.

4）麓 英彦, 竹村冨男：木材学会誌 29(2), 97104 (1983)

5）末吉修三, 斎藤寿義, 葉石猛夫：木材学会誌 33(5), 367-375 (1987).

6）信田 聡：木材学会誌 34(5), 388-394 (1988).

7）信田 聡：木材学会誌 34(7), 574-580 (1988).

8) Wang, S., Liau, C. : Mokuzai gakkaishi 43(1), 2437 (1997)

9）師岡淳郎, 則元 京, 磯田憲生：木材学会誌 46(5), 421-430 (2000).

10）関野 登, 河村義大, 山内 剛：木材学会誌 51 (6), 380-386 (2005).
11）関野 登, 山内 剛：木材学会誌 $53(2), 104-$ 109 (2007)

12）大澤徹夫, 水谷章夫, 土川忠浩, 小野公平：日本 建築学会計画系論文集 488,9-15（1996）.

13）古川和仁, 佐々木康寿, 平嶋義彦, 榊原勝己： 2006年度日本木材学会中部支部大会要旨集, 松 本, 2006, p. 10.

14）佐々木康寿, 古川和仁, 平嶋義彦, 渡邊 拡, 榊 原勝已：第57回日本木材学会大会要旨集, 広 島, 2007, G08-1115.

15）山崎真理子, 崔哲, 水谷章夫, 佐々木康寿, 平野佳祐, 榊原勝已：第58回日本木材学会大会 要旨集,つくば, 2008, pp. 161-162.

16）佐々木康寿, 山崎真理子, 平野佳祐, 水谷章夫, 榊原勝已：第58回日本木材学会大会要旨集, つ くば, 2008, pp. 163-164.

17）宮野秋彦：“建物の断熱と防湿”, 学芸出版社, 京都, 1981, pp. 24-33.

18）宮野則彦, 宮野秋彦：熱物性 21 (4), 193-199 (2007). 